\title{
BREAKDOWN CAUSE AND EFFECT ANALYSIS. CASE STUDY
}

\author{
Witold BIA $\mathrm{tY}$ \\ Silesian University of Technology \\ Juraj RUŽBARSKÝ \\ Technical University of Košice
}

\begin{abstract}
:
Every company must ensure that the production process proceeds without interferences. Within this article, the author uses the term "interferences" in reference to unplanned stoppages caused by breakdowns. Unfortunately, usually due to machine operators' mistakes, machines break, which causes stoppages thus generating additional costs for the company. This article shows a cause and effect analysis of a breakdown in a production process. The FMEA as well as quality management tools: the Ishikawa diagram and Pareto chart were used for the analysis. Correction measures were presented which allowed for a significant reduction in the number of stoppages caused by breakdowns.
\end{abstract}

Key words: analysis, production process, breakdown, FMEA, Ishikawa diagram, Pareto chart

\section{INTRODUCTION}

The goal of every company in the market is quick, dynamic development, which will cause the company to be noticed, bring profits, and become competitive. As a result of these as well as other, not quality-related actions, the company will keep its regular clients and gain new ones. To meet the ever increasing client expectations, the company has to ensure that the production process proceeds without interferences. Unplanned interferences in the production process affect the quality and timeliness of the tasks performed. Unplanned production stoppages include stoppages caused by machine/equipment breakdown. Each breakdown means additional costs incurred by the company.

Economic changes over the recent years caused the quality of products and services to become the key criterion affecting a company's success. That is why, in their production practice, companies use quality management systems increasingly often. The principles, methods and tools used in quality management allow us to easily and effectively determine the cause of a breakdown and subsequently introduce measures aimed at preventing such breakdowns in the future.

Quality management has been used in the general company management system. The goal is to improve the company's market position as a result of increased product and service quality. This is connected with a certain management approach, a type of company culture. In order to properly, effectively manage quality, the management staff requires information which needs to be reliable, up to date and correct. Therefore, quality management tools are used to gather and process information, supervise processes, detect errors, defects and anomalies in processes, products or services.
The advancement of information technologies utilising mechanical-electronic systems introduced a "new quality" in the construction and use of machines. The application of control, monitoring and regulating units and systems allows for properly carrying out production tasks. It has become the standard to monitor the status of machines before, during and after work. As a result of this, the number of stoppages during the production process was reduced quite significantly, which translates into economic results of companies.

\section{QUALITY PRINCIPLES, METHODS AND TOOLS}

The principles of quality management define the relationship of the company and its employees with the broadly-defined quality problems. The influence on quality is long -term and determines the company's development strategy.

Quality management principles (QMP) and quality management tools (QMT) are used at all stages in the product's life cycle, while quality management methods (QMM) are directed precisely at particular stages of that cycle.

Quality management methods are characterised by a planned, repeatable method of conduct based on a scientific basis for carrying out tasks connected with quality management. It is assumed that impact on quality is medium-term, allows for shaping the project and delivery quality.

Quality management tools are used for gathering and processing data connected with various aspects of quality management - the impact on quality is short-term.

Table 1 presents in a simplified manner the principles, methods and tools of quality management [1, 2]. 
Table 1

Principles, methods, tools of quality management

\begin{tabular}{lll}
\cline { 2 - 3 } & \multicolumn{1}{c}{ Characteristics and impact on quality } & \multicolumn{1}{c}{ Examples } \\
\hline QUALITY MANAGEMENT & - general guidelines for conduct, & - DEMING's guidelines, \\
PRINCIPLES (QMP) & - their scope goes beyond the company itself. & - continuous process improvement principle, \\
& & - "zero defects" principle, \\
QUALITY MANAGEMENT & - planned method of conduct based on algorithms, & - Teamwork method (quality circles, task \\
METHODS (QMM) & - for shaping project & teams), \\
& - and delivery quality, "medium-term" impact. & - QFD, \\
& & - value analysis, \\
QUALITY MANAGEMENT & - used for fathering and processing data, & - FMEA (AMDEC), \\
TOOLS (QMT) & - the results can be used almost immediately, & - SKO, \\
& - effectively used along with quality management & - SPC. \\
methods. & - Pareto chart, \\
& & - histogram, \\
& & - control sheets, \\
\hline
\end{tabular}

\section{PRODUCTION SYSTEM, PRODUCTION PROCESS}

By production system we understand a system of constituent elements and their relations as well as the relations of transformation of input factors into output factors. It is a purposefully designed and organised material, energetic and information system used for the production of products (goods, services) in order to satisfy the consumers' needs [3]. A production process is an element of the production system - it is the process of transformation of an input vector of the production system into an output one. Production processes can be observed everywhere where broadly-defined production takes place, but also in the service sector. That is why the following definition is often used: a production process is an ordered series of actions resulting in the consumer (user) receiving a product (goods, services).

This article presents a production process of a two-part toothed rim and the cause and effect analysis of this process that has been conducted. To this end, methods and tools of quality management were used.

Three machines are used in the production process of the two-part toothed rim: plate-typed milling and boring machine (Fig. 1), turning lathe (Fig. 2) and a toothed rim machining tool (Fig. 3).

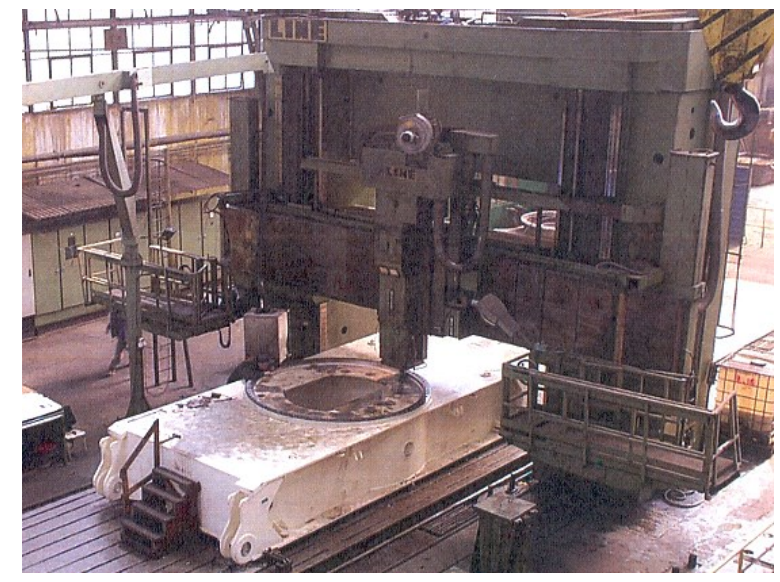

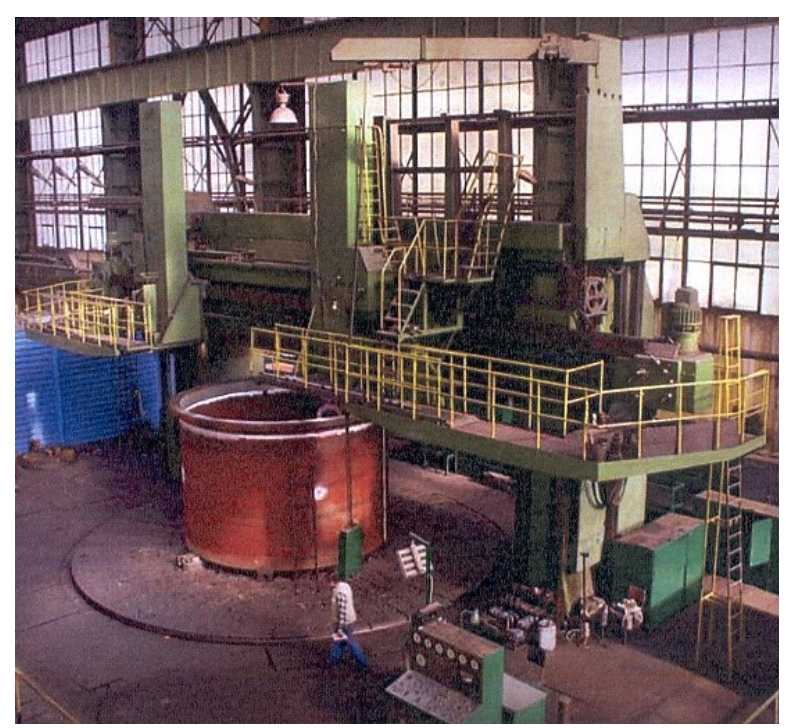

Fig. 2 Turning lathe

Source: [5].

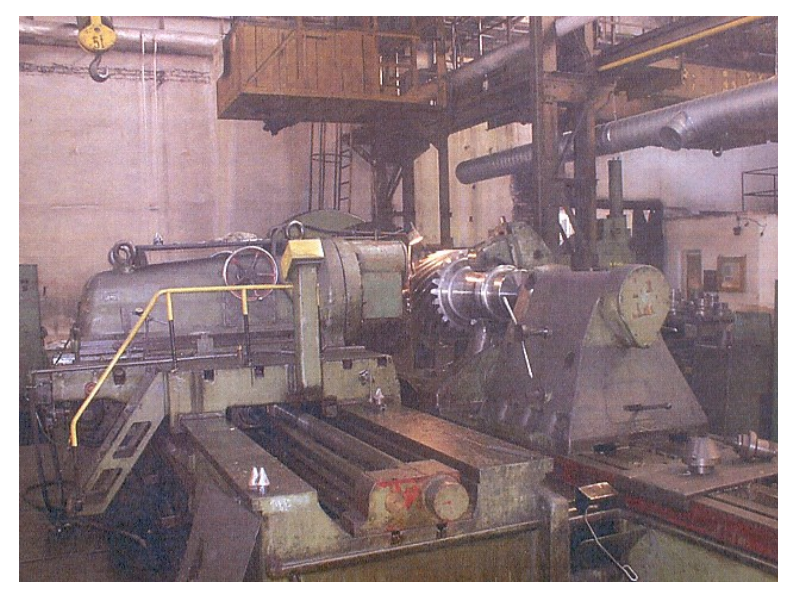

Fig. 3 Toothed rim machining tool

Source: [5].

Fig. 1 Milling and boring machine

Source: [5]. 
The output material is a steel cast with surface surpluses which undergo processing. Upon checking that the cast has been made properly on a surface plate, the cast is sent forward for further operations. The first machine is the board-typed milling and boring machine where the contact surfaces and holes for the screws holding the rim together (Fig. 1). Next, the inner diameter is lathed - this operation is carried out on a turning lathe (Fig. 2). After a correctness control, the element is passed onto the hobber (Fig. 3) where the teeth are machined.

\section{ANALYSIS OF MACHINE BREAKDOWN IN THE PRODUCTION PROCESS}

A failure frequency analysis has been carried out for the turning lathe (Fig. 2) The failure was caused by the breaking of the counterweight cable, which immobilised the machine. The lathe was completely excluded from the production process for a period of five days - during this time the slide was being dismounted (chart - Fig. 4).
After dismounting the slide, the machine worked with one slide only, which allowed it to reach half of its operational capability (Fig. 4). Next, after completion of all the parts and repair, the slide was mounted, which immobilised the lathe for a further five days. The total duration of the breakdown was 17 days and the repair costs amounted to approximately PLN 17,000. These, however, are not the only costs incurred by the company due to the machines unsuitability for work. The production process was halted, for 10 days no actions were performed. As a result of the breakdown, delivery to the client was delayed by 17 days [4].

In order to determine the cause for the breaking of the counterweight cable, a team of employees was assembled and a "brainstorm" conducted in order to identify the problem. Following that, an Ishikawa diagram [7, 9] was drawn up, determining the primary as well as secondary causes (Fig. 5).

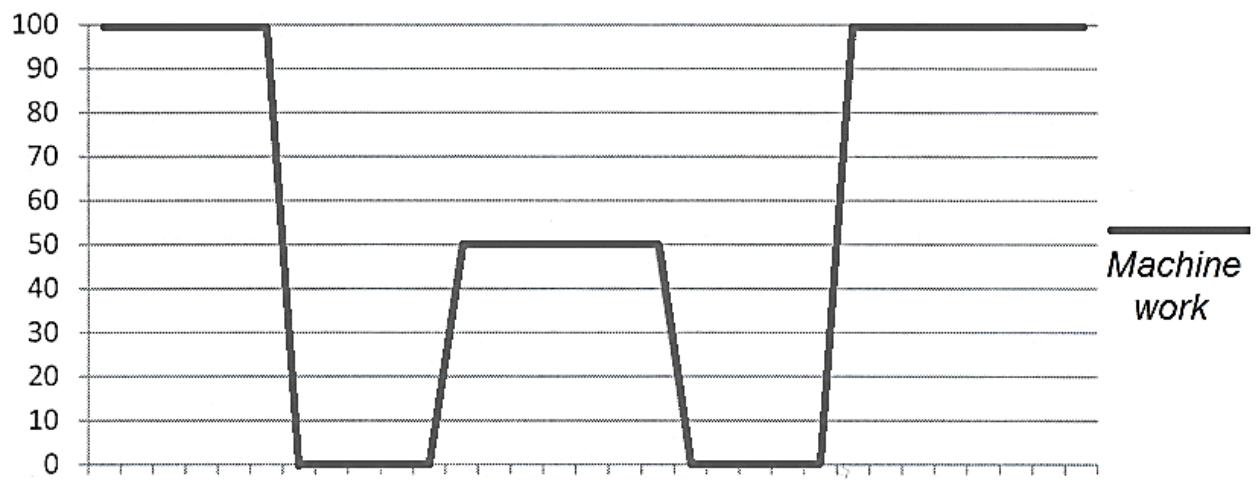

12345678910111213141516171819202122232425262728293031

Fig. 4 Machine working efficiency chart

Source: [4].

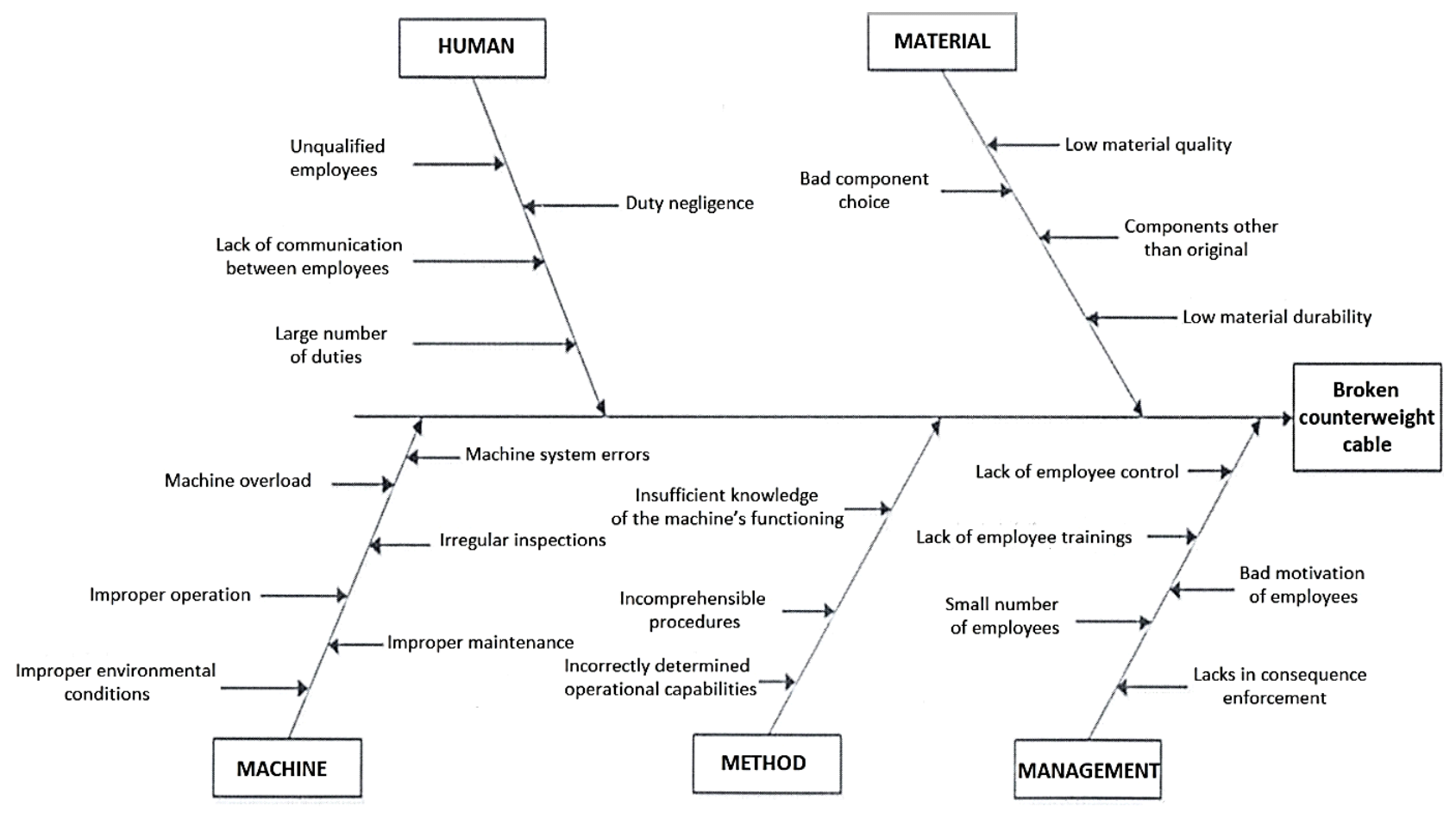


The aim of this method is to identify the causes of potential or past endeavour failures. That is why the method is also referred to as the cause and effect chart and, due to its characteristic appearance - the fishbone chart.

The diagram is a result of the work of many employees, as causes of failures often have their roots in multiple areas of activity. That is why the team should consist of individuals with extensive specialist knowledge, who also want to discover the causes of failures, including those they themselves caused. Using the heuristic method model when assembling the team is very useful.

The Ishikawa diagram presented was created as a result of work of many company employees, specialists with extensive knowledge on the operation and functioning of the turning lathe. The diagram shows potential causes which may have impacted the lathe's failure. As a result of the analysis conducted it was concluded that the direct cause of the cable breaking was its natural wear and tear - the cable was not replaced in time.

Following that, an FMEA (Failure Mode and Effects Analysis) was conducted - an analysis of the types and consequences of potential errors $[6,8]$. This method is aimed at preventing the consequences of defects which may occur in the design and production stages. Potential defects which may occur and cause the breaking of the counterweight line. the assessment was conducted using a ten-point scale with three criteria were taken into account:

- risk of the defect occurring $-\mathrm{R}$,

- possibility of detecting the cause of the defect $-W$,

- importance of the defect to the end user $-Z$.

For these three criteria a figure $P$ was calculated, which indicates what defect can occur the soonest and should be treated with the most attention.

$$
\mathrm{P}=\mathrm{R} \cdot \mathrm{W} \cdot \mathrm{Z}
$$

The FMEA for the counterweights cable breaking case was shown in Table 2.

As a result of the FMEA conducted it was concluded that the machine's technical condition has a significant impact on its failure frequency. Special attention should be paid to all the sensors and switches, as the failure in this case is caused only by the machine's technical condition. The human and material factors do not play a role in the failure. Corrective measures introduced caused a reduction of the P figure by almost a half for each of the defects. Table 3 presents the results of the corrective measures.

Based on the data contained in Table 3, a Pareto [9] chart was created in order to indicate which defects have the biggest impact on failures (Fig. 6).

Table 2

FMEA for the broken counterweight cable

\begin{tabular}{|c|c|c|c|c|c|c|c|c|c|c|c|c|c|}
\hline \multirow{2}{*}{$\begin{array}{l}\text { Defect } \\
\text { No. }\end{array}$} & \multirow{2}{*}{$\begin{array}{l}\text { Potential de- } \\
\text { fect }\end{array}$} & \multirow{2}{*}{$\begin{array}{l}\text { Potential con- } \\
\text { sequences of } \\
\text { the defect }\end{array}$} & \multirow{2}{*}{$\begin{array}{c}\text { Potential } \\
\text { causes of } \\
\text { the defect }\end{array}$} & \multirow{2}{*}{$\begin{array}{l}\text { Preventive } \\
\text { measures }\end{array}$} & \multirow[t]{2}{*}{$\mathbf{R}$} & \multirow[t]{2}{*}{$\mathbf{w}$} & \multirow[t]{2}{*}{ 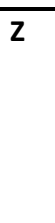 } & \multirow[t]{2}{*}{$\mathbf{P}$} & \multicolumn{5}{|l|}{ Measure results } \\
\hline & & & & & & & & & $\begin{array}{l}\text { Measures aimed } \\
\text { at improving the } \\
\text { detectability } \\
\text { of the defect }\end{array}$ & $\mathbf{R}$ & $\mathbf{w}$ & $\mathrm{Z}$ & $\mathbf{P}$ \\
\hline 1 & $\begin{array}{l}\text { Cable wear } \\
\text { and tear }\end{array}$ & $\begin{array}{l}\text { Cable breaking, } \\
\text { immobilisation } \\
\text { of the machine }\end{array}$ & $\begin{array}{l}\text { Cable not } \\
\text { replaced } \\
\text { in time }\end{array}$ & $\begin{array}{l}\text { Replacing } \\
\text { the cable } \\
\text { in time }\end{array}$ & 2 & 3 & 5 & 30 & $\begin{array}{l}\text { Systematic periodical } \\
\text { cable replacement }\end{array}$ & 1 & 3 & 5 & 15 \\
\hline \multirow[t]{2}{*}{2} & $\begin{array}{l}\text { Low quality } \\
\text { of the cable }\end{array}$ & $\begin{array}{l}\text { Cable chaffing, } \\
\text { cable breaking, }\end{array}$ & $\begin{array}{l}\text { Bad choice } \\
\text { of supplier }\end{array}$ & $\begin{array}{l}\text { Choosing } \\
\text { one supplier }\end{array}$ & 3 & 1 & 8 & 24 & Supplier selection & 1 & 1 & 8 & 8 \\
\hline & material & $\begin{array}{l}\text { immobilisation } \\
\text { of the machine }\end{array}$ & $\begin{array}{l}\text { Attempt } \\
\text { at cost } \\
\text { reduction }\end{array}$ & $\begin{array}{l}\text { Buying } \\
\text { original parts }\end{array}$ & 3 & 1 & 8 & 24 & Original parts & 1 & 1 & 8 & 8 \\
\hline 3 & $\begin{array}{l}\text { Lack of } \\
\text { reaction } \\
\text { of the limit- } \\
\text { switches }\end{array}$ & $\begin{array}{l}\text { Cable breaking, } \\
\text { halting } \\
\text { the production } \\
\text { process }\end{array}$ & $\begin{array}{l}\text { Machine } \\
\text { system } \\
\text { error }\end{array}$ & $\begin{array}{l}\text { Checking } \\
\text { the ma- } \\
\text { chine's con- } \\
\text { dition more } \\
\text { frequently }\end{array}$ & 4 & 2 & 9 & 72 & $\begin{array}{l}\text { More frequent } \\
\text { maintenance, } \\
\text { checking the } \\
\text { machine's technical } \\
\text { condition }\end{array}$ & 2 & 2 & 9 & 36 \\
\hline 4 & $\begin{array}{l}\text { Improper } \\
\text { shutting down } \\
\text { of the } \\
\text { machine }\end{array}$ & $\begin{array}{l}\text { Cable breaking, } \\
\text { machine } \\
\text { shutting down }\end{array}$ & $\begin{array}{l}\text { Machine } \\
\text { operator's } \\
\text { mistake }\end{array}$ & $\begin{array}{l}\text { Increasing } \\
\text { the opera- } \\
\text { tors' qualifi- } \\
\text { cations }\end{array}$ & 2 & 1 & 9 & 18 & $\begin{array}{l}\text { Control of operators' } \\
\text { qualifications, } \\
\text { employee trainings }\end{array}$ & 1 & 1 & 9 & 9 \\
\hline
\end{tabular}

Table 3

Change in values after corrective measures

\begin{tabular}{|c|c|c|c|c|}
\hline \multirow[t]{2}{*}{$\begin{array}{c}\text { Number of } \\
\text { defects }\end{array}$} & \multicolumn{2}{|c|}{$\underset{P}{\text { Sum }}$} & \multicolumn{2}{|c|}{$\begin{array}{c}\text { The cumulated } \\
\text { value [\%] }\end{array}$} \\
\hline & before & after & before & after \\
\hline 1 & 30 & 15 & $18 \%$ & $9 \%$ \\
\hline 2 & 48 & 16 & $29 \%$ & $10 \%$ \\
\hline 3 & 72 & 36 & $42 \%$ & $22 \%$ \\
\hline 4 & 18 & 9 & $11 \%$ & $5 \%$ \\
\hline
\end{tabular}




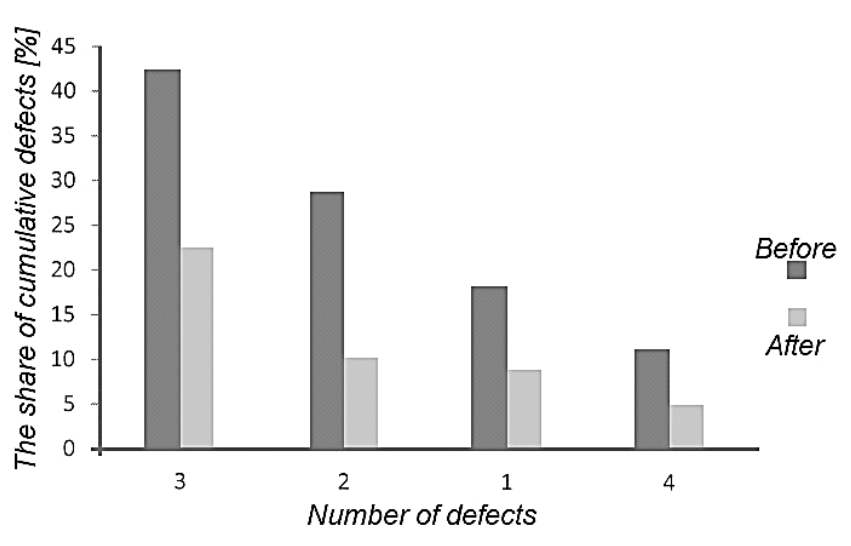

Fig. 6 Pareto chart for the counterweight cable

\section{CONCLUSION}

The production process of a two-part toothed rim analysed in this article is not a complex one. Nevertheless, the final product, its quality as well as the proper functioning of the entire technical system is affected by many factors. Among them are both the material and other factors affecting the proper operation of the machine. The article analyses one type of failure (breaking of the counterweight cable) in one of the three machines which take part in the production process. As a result of this breakdown, the company suffered both financial and reputational losses. Delivery of the complete element to the client was delayed by over two weeks, the entire production process was halted, which resulted in a delay in the completion of all orders.

The conducted analyses (FMEA, Ishikawa diagram, Pareto chart) [9] allowed identifying the defects which have a direct impact on breakdowns. The quality management tools and methods used in the analysis can help to establish what kind of defects and failures may occur, what was their cause and what actions need to be taken to prevent shutdowns resulting from failures. Preventive (corrective) actions have been taken so as to prevent failures in the future. Furthermore, activities aimed at improving the detectability of defects have been undertaken, which will considerably reduce or minimize the risk of breakdowns.
As a result of these activities, downtimes of machines in the production process will be reduced, and, in consequence, order delivery deadlines will be met. The image of the company as a reliable contractor will improve, which should translate into an increased number of orders.

This article was prepared within the statutory research titled "Methods and tools for improving products and services on the selected examples" work symbol 13/030/BK_17/0027 performed at Silesia University of Technology, Institute of Production Engineering.

\section{REFERENCES}

[1] J. Dahlgaard, K. Kristesen and G. Kanji, Podstawy zarzq̨dzania jakościq. Warszawa: Wydawnictwo Naukowe PWN, 2000.

[2] S. Wawak, Zarzqdzanie jakościq - Teoria i praktyka. Gliwice: Helion, 2002.

[3] I. Durilk, Inżynieria zarzqdzania Cz. II - strategie wytwarzania. Gdańsk: Wydawnictwo Placet, 2005.

[4] Ż. Gwóźdź, „Wpływ awarii na dany proces produkcyjny", Eng. thesis, Faculty of Organization and Management, Silesian University of Technology, Zabrze, 2017.

[5] Zamet Industry S.A. website. (2017, Feb. 22). Zamet Industry [Online]. Available: http://www.zametindustry.com.pl

[6] M. Urbaniak, Zarzqdzanie jakościq. Warszawa: Wydawnictwo Difin, 2004.

[7] B. Szczęśniak, M. Zasadzień and Ł. Wapienik, „Zastosowanie analizy Pareto oraz diagramu Ishikawy do analizy przyczyn odrzutów $\mathrm{w}$ procesie produkcji silników elektrycznych", Zeszyty Naukowe Politechniki Ślq̨skiej, s. Organizacja i Zarzq̨dzanie, vol. 63a, pp. 125 $-147,2012$.

[8] H. Gołaś and A. Mazur, Zasady, metody i techniki wykorzystywane w zarzqdzaniu jakościq. Poznań: Wydawnictwo Politechniki Poznańskiej, 2010.

[9] K. Midor, „Innovations in the field of enterprise quality management as an element of sustainable development implementation" 14th International Multidisciplinary Scientific GeoConference SGEM, Albena 2014, Vol. 3, pp. 215-223

\footnotetext{
dr hab. inż. Witold Biały, prof. PŚ.

Silesian University of Technology

Faculty of Organization and Management

Institute of Production Engineering

ul. Roosevelta 26, 41-00 Zabrze, POLAND

e-mail: witold.bialy@polsl.pl

Doc. Ing. Juraj Ružbarský, PhD

Technical University of Košice

Faculty of the Manufacturing Technologies

Department of Manufacturing Processes Operation

Letná 9, 04200 Košice, SLOVAK REPUBLIC

e-mail: juraj.ruzbarsky@tuke.sk
} 